\title{
Bowen Ratio Method for Measuring Heat Transfer on Land Cover Change in Establishing Green Patch in Urban Heat Island of Bangkok
}

\author{
Alongkorn Intaraksa ${ }^{1}$, Kasem Chunkao ${ }^{1} \&$ Surat Bualert ${ }^{1}$ \\ ${ }^{1}$ Department of Environmental. Science, Faculty of Environment, Kasetsart University, Bangkok, Thailand \\ Correspondence: Alongkorn Intaraksa, Department of Environmental. Science, Faculty of Environment, \\ Kasetsart University, Bangkok 10900, Thailand. E-mail: a_intaraksa@hotmail.com
}

Received: May 20, 2014

Accepted: June 10, $2014 \quad$ Online Published: June 25, 2014

doi:10.5539/mas.v8n4p158

URL: http://dx.doi.org/10.5539/mas.v8n4p158

\begin{abstract}
Due to the rapid growth of urban heat island (UHI) in Bangkok, which is covered by $1,568.7 \mathrm{sq} . \mathrm{km}$ and $1.5 \mathrm{mMSL}$ and surrounded by the Gulf of Thailand and Chao Phraya river, has been gradual.ly extended through suburban areas that making ambient air temperature increased about $0.03{ }^{\circ} \mathrm{C} / \mathrm{y}$ for 56 -year period (1957 to 2013). The Bowen ratio found between 3.20 to 3.25 that required to select the green patches $25 \%$ to $75 \%$ of the total landscape for enough heat absorbent from urban heat island in Bangkok city that being full of concrete construction and dense population. Landscape design for reduction heat from UHI unit areas should be considered in four orders of magnitude, i.e., landscape macro-designing, green patch localization, cooling housing design and construction, and housing landscape design.
\end{abstract}

Keywords: Bowen Ratio, heat transfer, land cover change

\section{Introduction}

The rapid growth of cities has been found all over the world since the last five decades due to the population explosion, following by constructing roads/streets, houses, shop houses, buildings, religious places, government office buildings, schools/colleges/universities, and any public construction units. Evidently, the cities have been enlarged together with big and tall builds to form the heat islands that made climate warm because of re-radiating from constructed buildings. Moreover, most of the cities laid the foundation in the old days without care for well-planned cities in arrangement of roads/streets, houses, shop houses, private buildings, government office buildings, religious places, schools/colleges/universities, and some constructed units. Although the city planning is proposed to exist the green patch areas for some criterion in order to provide the city residences to use for exercising, relaxing, and recreational activities. In other words, the heat islands, in general, are the areas which include smaller green patches due to high dense buildings as main sources for re-radiating to increase higher temperature (Caseo \& Larsen, 2012; Oke et al., 1991; Alchapar et al., 2014; Takebayashi et al., 2014; Ketterer and Matzarakis, 2014). As understood among scientists, the higher temperature can be reduced by using latent heat for vaporization which is equivalent to 583 calories per one gram of water to escape from water surface to the sky, and al.so its amount is the same as transpiration of vegetation.

So, the best way to lower air temperature in heat island by constructing water storage ponds and/or panting green patches in order to encourage heat absorption by evapotranspiration water to the sky (Linsley et al., 1988; Chunkao, 2008; Sellers, 1969; Penman, 1948; Bowen, 1926). In principles, such amount of heat-released water is depended on size of surface water as water availability together with wind direction and speed, water and air temperature, vapor pressure; and al.so related to plant species, age, size, leaf area index, and areal size of green patches as well as topographical characteristics (elevation, slope, aspect, landform) and seasonal periods (Chunkao, 1979, 2008; Zhang et al., 2013; Ketterer, 2014). Naturally, the occurrence of evapotranspiration process can be existed either low or high temperature because of the vertical vapor pressure gradient between evaporating surface and upper edge of boundary layer which is supported by withdrawing forces of wind speed and surrounding temperature (Linsley et al., 1988; Chunkao, 1971; Deacon, 1949). In other words, the way how to decrease the air temperature could be implemented by growing green patches as the same as construction of water-storage ponds in order to absorb heat in form of evapotranspiration, about 583 calories per a gram of evaporated water.

Actually, the urban heat island is the area (municipal, urban, suburban and dense-populated community areas) to 
elevated temperature (ground surface and air temperature), air pollution, and energy consumption. It is normally surrounded by big and tall buildings, houses, shop houses, religious buildings, green roof, green patches, city parks, and ponds in which they play significant role in function on sources and sinks for day and night heat balance (Santamouris, 2012; Caseo \& Larsen, 2014; Chun \& Guldman, 2014; Honjo \& Takakura, 1990; Oke et al., 1991; Lokoshchenko, 2014; Santamouris, 2001; Maimaitiyiming et al., 2014) in which they come hand in hand with the rapid-unplanned urban growth and high density of population such as Ketterer and Matzarakis (2014) found out UHI increasing $0.3{ }^{\circ} \mathrm{K}$ to $2{ }^{\circ} \mathrm{K}$ and up to $12^{\circ} \mathrm{K}$ in the city concrete; $1.5-3.0^{\circ} \mathrm{C}$ per 100 years; $2{ }^{\circ} \mathrm{C}$ for $17.25 \%$ building cooling energy use by Sun and Augenbroe $(2014) ; 1{ }^{\circ} \mathrm{C}$ to $5{ }^{\circ} \mathrm{C}$ from air conditioning units by Caseo and Larsen (2014); and average monthly $2.6^{\circ} \mathrm{C}$ in urban heat island by Shahidan et al. (2012). There were a lot of research reports concerning with decreasing air temperature in heat island areas by either growing green patch or storage water ponds such as Skoulika et al. (2014) found nocturnal cool islands varying $0.7^{\circ} \mathrm{K}$ to $2.8^{\circ} \mathrm{K}$ and daytime $0.2^{\circ} \mathrm{K}$ to $2.6^{\circ} \mathrm{K}$ from ambient temperature lower than $34{ }^{\circ} \mathrm{C} ; 1.3 \mathrm{~V}$ and decreasing $0.2{ }^{\circ} \mathrm{C}$ for every $10 \%$ increase from the study of Caseo and Larsen (2014); $2.14{ }^{\circ} \mathrm{C}$ to $5.15{ }^{\circ} \mathrm{C}$ together with increasing relative humidity $6.21 \%$ to $8.30 \%$ by Zhang et al. (2013); $0.9^{\circ} \mathrm{K}$ and found $0.1^{\circ} \mathrm{K}$ to $0.33^{\circ} \mathrm{K}$ per roof albedo increase by Santamouris (2012).

Giving green patches and tree planting in urban heat island have been recommended by Mangone and Linden (2014), Akbari et al. (1992), McPherson (1988), McPherson and Simpson (1992), McPherson and Rowntree (1993), Caseo and Larsen (2014), Zhang et al. (2013), Honjo and Takakura (1990), Alchepar et al. (2014), Oke et al. (1991), Shahidan et al. (2012) while Chun and Guldman (2014) recommended to establish the roof-top green patch and water areas for reduction of urban heat islands as well as giving vegetated courtyard and city parks by Mangone and Linden (2014), Skoulika et al. (2014), and McPherson (1988), Takebayashi et al. (2014), $\mathrm{Ng}$ et al. (2012); and also making higher albedo roof by Alchapar et al. (2014). In principles, an incoming heat protection (such as tree planting, pond construction, green patch making on building-top roof, and increasing albedo of around buildings) in urban heat island would be the most important to reduce ambient air temperature due to make them away from exactly sources and sink in heat transfer by re-radiation and heat absorption before re-radiation which are the heating processes concerning in decreasing rather than increasing ambient air temperature in heat islands in rapid growth cities and communities.

To accomplish such above principles, the incoming heat occurrence has to be understood and know how to measure it in order to take it as the main factor to make heat island for landscape designing to reduce ambient air temperature of heat islands in the dense-populated cities and communities. Following the said information, heat balance measurement should be firstly conducted as expressed by Deacon (1949), Sellers (1969), Chunkao (1979, 2008), Uddin et al. (2013), Savage et al. (2009), an Takebayashi et al. (2014) as followed:

$$
\mathrm{R}_{\mathrm{n}}+\mathrm{LE}+\mathrm{H}+\mathrm{G}+\mathrm{Ph}+\mathrm{M}+\mathrm{C}=0
$$

where

$$
\mathrm{Rn}=\text { net radiation flux, } \mathrm{cal} / \mathrm{m} 2 / \mathrm{min}
$$

$\mathrm{LE}=$ latent heat flux, $\mathrm{cal} / \mathrm{m} 2 / \mathrm{min}$, which $\mathrm{L}$ is equivalent to latent heat of water vaporization

$(583 \mathrm{cal} / \mathrm{g})$ and $\mathrm{E}$ is evaporated water $(\mathrm{mm})$

$$
\begin{aligned}
& \mathrm{H}=\text { sensible heat flux, } \mathrm{cal} / \mathrm{m}^{2} / \mathrm{min} \\
& \mathrm{G}=\text { soil heat flux or ground surface heat flux, cal } / \mathrm{m}^{2} / \mathrm{min} \\
& \mathrm{Ph}=\text { photosynthesis heat flux, } \mathrm{cal} / \mathrm{m}^{2} / \mathrm{min} \\
& \mathrm{M}=\text { metabolism heat flux, } \mathrm{cal} / \mathrm{m}^{2} / \mathrm{min} \\
& \mathrm{C}=\text { chemical processing heat flux, } \mathrm{cal} / \mathrm{m}^{2} / \mathrm{min}
\end{aligned}
$$

For bare land and human settled land as well as city and dense-populated communities, the quantity of $\mathrm{Ph}, \mathrm{M}$, and $\mathrm{C}$ are very less. Therefore, the equation (1) can be expressed as followed

$$
\mathrm{R}_{\mathrm{n}}+\mathrm{LE}+\mathrm{H}+\mathrm{G}=0
$$

and it can re-write in another balance as

$$
\mathrm{LE}+\mathrm{H}=-\left(\mathrm{R}_{\mathrm{n}}+\mathrm{G}\right)
$$

In practical implementation, Rn and $\mathrm{G}$ can be directly measured by Net Radiation Meter and Soil Heat Flux Meter, respectively, but LE and $\mathrm{H}$, which play vital role in urban heat islands, have to calculated rather than direct measurement. In meteorological and hydrological points of views, Bowen (1926) used Bowen ratio for describing the type of heat transfer in a water body in which heat transfer can either occur as sensible heat 
(differences in temperature without evapotranspiration) or latent heat (the energy required during a change of state, without a change in temperature). In other words, the Bowen ratio is the mathematical method generally used to calculate heat lost (or gained) in a substance, it is the ratio of energy fluxes one state to another by sensible and latent heating, respectively. Bowen (1926) expressed Bowen ratio and modified by Savage et al. (2009), Chunkao (1979, 2008), Dicken et al. (2013), Holland et al. (2013), Peres et al. (1999), Uddin et al. (2013), Wolf et al. (2008), and Takebyashi et al. (2014) as followed

$$
\text { Bowen Ratio }(B)=H / L E
$$

If $\mathrm{B}$ is less than one, great portion of available energy at the surface is passed to the atmosphere as latent heat than sensible heat, and the converse is true for value of B greater than one. In general, the value of B is equivalent to $0.41+/-0.07$ for temperate forest area and grassland, 0.2 for tropical rainforest, 0.1 for Tropical Ocean, about 10 for desert, 2.0-6.0 for semi-arid region (Bowen, 1926; Dicken et al., 2013). Actually, when the evaporation is low, because water supply is limited, B value tends to be high. For convenience to calculate LE and $\mathrm{H}$, the Equation (4) is presumed to replace in equation (3) as done by Holland et al. (2013), Savage et al. (2009), Peres et al. (1999), Dicken et al. (2013), the result will be as

$$
L E=-\left(R_{n}+G\right) /(1+B)
$$

and also,

$$
H=-B\left(R_{n}+G\right) /(1+B)
$$

It is quite evident that either $\mathrm{LE}$ or $\mathrm{H}$ can be calculated in case of values of $\mathrm{Rn}$ and $\mathrm{G}$ can be directly measured by specific instruments. In bare land and city, the value of $\mathrm{G}$ for 24 hours is close to zero, particularly in the tropical zone (Gate, 1962; Chunkao, 1971, 1979) the G flux in Equations (5) and (6) can be represented in zero for calculation. In addition, the B value can be determined from vertical movement of LE in elevation difference $(\mathrm{dz})$ of evaporated water vapor (e) in terms of vapor pressure gradient (de/dz), and $\mathrm{H}$ in temperature difference $(\mathrm{dT} / \mathrm{dz})$ that can be expressed as follows:

$$
\begin{gathered}
H=-p C p K h(d T / d z), L E=-(p C p / r) K v(d T / d z) \\
B=H / L E=[p C p K h(d T / d z)] /[(p C p / r) \operatorname{Kv}(d T / d z)]
\end{gathered}
$$

where

$$
\mathrm{Kh}=\text { turbulent coefficient for sensible heat, }
$$

$\mathrm{Kv}=$ turbulent coefficient for water vapor,

$\mathrm{Kh}=\mathrm{Kv}$ as assumed by Verma et al. (1978) and measuring the temperature and vapor pressure gradients between two levels within the adjusted surface layer,

$\mathrm{p}=$ air density $(\mathrm{g} / \mathrm{m} 3)$,

$\mathrm{Cp}=$ specific heat of air $(0.24 \mathrm{cal} / \mathrm{g} / \mathrm{cc})$. If $\mathrm{P}=$ atmospheric pressure $(1,000 \mathrm{mb})$,

$\mathrm{Mw}=$ molecules of wet air,

$\mathrm{Md}=$ molecules of dry air, and $\mathrm{y}=\mathrm{Mw} / \mathrm{Md}=0.622$, then the equation (8) can rewrite as

$$
\mathrm{B}=\mathrm{r}(\mathrm{dT} / \mathrm{dz}) /(\mathrm{de} / \mathrm{dz})=\mathrm{r}(\mathrm{dT} / \mathrm{de})
$$

$r$ is psychometric constant $(\mathrm{CpP} / \mathrm{yL})$, then $\mathrm{B}$ is obtain

$$
\mathrm{B}=0.666(\mathrm{dT} / \mathrm{de})
$$

The Equation (10) is suited in determining B through measuring the differences of air temperature and vapor pressure between two levels close to the ground surface as boundary layer under laminar flow as recommended the different levels of $0.8 \mathrm{~m}$ by Takebayashi et al. (2014), $0.85 \mathrm{~m}$ by Ashktorab et al. (1989) and 2-8 $\mathrm{m}$ by Sellers (1969). Also, the measuring point should follow the H:W or building-height to street-width ratio in which the instrument should be installed at minimum elevation for measurements about three to five times the height of roughness elements (Garrat, 1978), while Heilman and Brittin (1989) recommended the fetch-to-height ratio equivalent to $20: 1$.

The previous statement is required to measure the concerned indicators such as $\mathrm{Rn}, \mathrm{G}$, Temperature, and vapor pressure for determining $\mathrm{LE}$ and $\mathrm{H}$ which are the main parameters to use for calculating Bowen ratio. Another way for calculated the Bowen ratio is placed on the measurement of air temperature and vapor pressure at two level under the laminar flow of horizontal wind speed which is very difficult to occur on the level near the earth's surface (Sellers, 1969; Uddin et al., 2013; Verma et al., 1978; Wolf et al., 2008). Consequently, Wolf et al. (2008) and Uddin et al. (2013) used the eddy covariance method for determining evapotranspiration; the results 
obtained were satisfied when they compared with the real situation. Naturally, the eddy (turbulent) transfer conditions are usually occurred in the atmosphere near the earth's surface even when the air very stable (Sellers, 1969). So, the better way to determine the heat, vapor pressure and momentum transfer near the ground have been recommended the eddy covariance method (sometime called eddy correlation method) by Wolf et al. (2008), Uddin et al. (2013), Verma et al. (1978) and Chunkao (1979). Actually, Sellers (1969) explained the latent heat and sensible heat fluxes from the ground surface in equation (7) in relation to vertical wind velocity (w) as

$$
\mathrm{LE}=-\mathrm{pL}(\mathrm{wq}), \quad \mathrm{H}=-\mathrm{pCp}(\mathrm{wT})
$$

Where

$\mathrm{p}($ rho $)=$ air density, $(\mathrm{g} / \mathrm{cc})$

$\mathrm{L}=$ latent heat of vaporization, $\left(583.2 \mathrm{cal} / \mathrm{g}\right.$ at $\left.15^{\circ} \mathrm{C}\right)$

$\mathrm{Cp}=$ specific heat coefficient of air, $(0.24 \mathrm{~g}$-cal $/ \mathrm{g})$

$\mathrm{T}=$ mean air temperature, $\left(273+{ }^{\circ} \mathrm{C}\right)$

$\mathrm{w}=$ mean vertical wind velocity, $(\mathrm{m} / \mathrm{sec})$

$\mathrm{LE}=$ latent heat flux, $\left(\mathrm{g}-\mathrm{cal} / \mathrm{cm}^{2} / \mathrm{sec}\right)$

$\mathrm{H}=$ sensible heat flux, $\left(\mathrm{g}-\mathrm{cal} / \mathrm{cm}^{2} / \mathrm{sec}\right)$

$\mathrm{q}=$ specific humidity, (ratio between mass of water vapor and mass of air)

moist air and dry air)

$\mathrm{q}=\mathrm{Mw} / \mathrm{Ma}(\mathrm{e}) /(\mathrm{P}-0.378), \mathrm{Mw} / \mathrm{Ma}=(18 / 28.9)=0.622,(\mathrm{Mw}$ and $\mathrm{Ma}=$ molecular weight of

$\mathrm{P}=\mathrm{Pa}+\mathrm{e}, \mathrm{Pa}$ dry vapor pressure $(\mathrm{mb}), \mathrm{e}=$ water vapor pressure $(\mathrm{mb})$

It is clearly understood that equation (11) can be usable for determining heat (LE and H), mutters, and momentum (Sellers, 1969) but it is still difficult to measure due to air movement near the ground, especially cities comprising of urban heat island, because of seriously eddy heat transfer. Hence, the Eddy Covariance Method (EC) has been proposed in using for measuring vertical transfer of heat and water vapor by eddies in the lower atmosphere (Swinbank, 1951) and followed by Verma et al. (1978), Wolf et al. (2008), Uddin et al. (2013) and Lee et al. (2004). Accordance with this applicably comprehensive academy, it made the Campbell Scientific's IRGASON, Incorporation (USA) has been invented the 3D Sonic Anemometer and HFPO1 and HFPO1SC for heat flux sensor in order to direct measurements of $R_{n}, L E, H$, Temperature, vapor pressure, and 3-dimension wind speeds $(\mathrm{v}, \mathrm{u}, \mathrm{w})$. These instruments are expected to answer the objectives of this research as a paved way to apply for planning to cool the urban heat island in Bangkok city.

The main objective of this study is aimed to find means how to reduce temperature in urban heat island of high-density city of Bangkok by increasing either stripped or patchy tree planting as the city parks as well as top-green roof or buffer zone by planting trees around the buildings. The aforesaid statement concerning urban heating is expected to obtain from an application of Bowen ratio methodology which leads to design the green patches as the mitigation measure for temperature reduction in Bangkok urban heat island to the normal conditions.

\section{Climate of Bangkok}

Bangkok is the capital of Thailand and located above $1.5 \mathrm{mMSL}$ on alluvial floodplain, the most suitable for growing paddy rice, between the latitudes of 13.5 degrees $\mathrm{N}$ and 13.9 degree $\mathrm{N}$, longitudes of 100.4 degrees $\mathrm{E}$ and 100.9 degrees E, and putting across the head of the Gulf of Thailand which is directly fed the freshwater flow from 5 main rivers, such as Bang Prakong, Chao Phraya, Thachin, Mae Klong, and Petchburi rivers. According to rapidly growing city in Thailand, Bangkok started having coverage area about $6.8 \mathrm{sq} . \mathrm{km}$ and horizontal.ly stretching the area size of 347.39 sq.km in 1996, 585.54 sq.km in 1996, 672.33 sq.km in 2000, and finally $1,568.7$ sq.km at the present time as shown in Figure1. Nowadays, there are legally population about 6 million plus illegally approximately 3 times for moving in chances of job opportunity, getting education, servicing government officials, international affairs, and tourists. Also, there are more 5 million people living in suburban provinces as Bangkok resident workers and factory labors. Those previous statement would be the basic causes to make high population density that followed urban heat island with warmer air temperature day by day. 


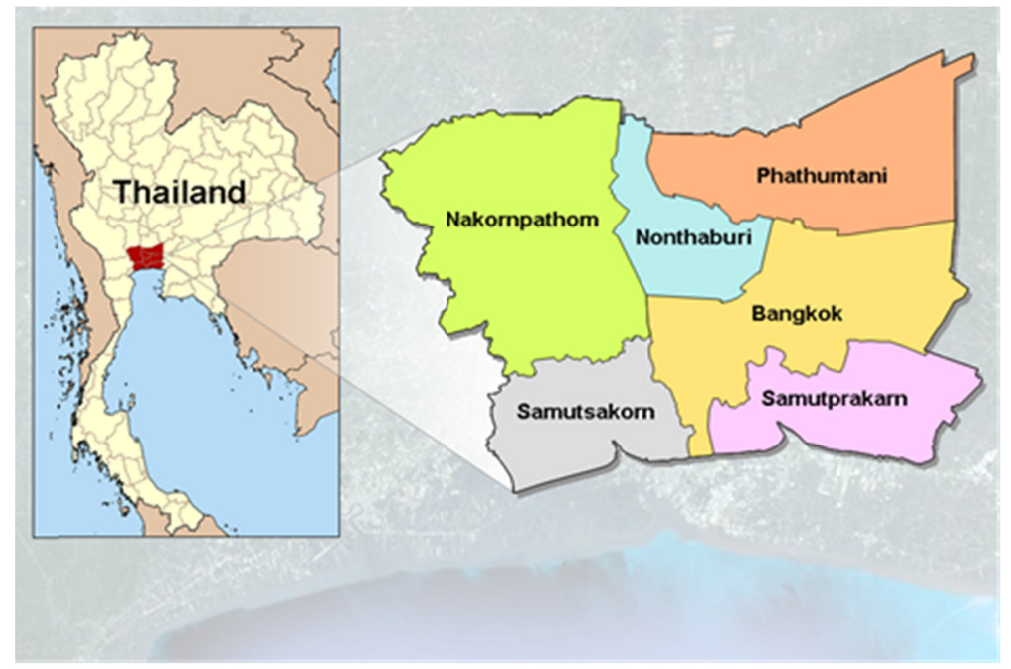

Figure 1. Location of Bangkok city and suburban areas in Samutsakorn, Nakhonprathom, Pratumthani, Chacherngsao, and Samutprakarn provinces including 156 man-made canals for detention storage of excess water after heavy rainstorms

In reality, the area of Bangkok city cannot be horizontal.ly expanded to all directions but its height growth has been replaced in terms of establishing households, shop houses, shopping centers, department stores, housing estates, tall buildings, entertaining buildings, commercial centers, outdoor and indoor recreational areas, and religious places but disorderly construction because of not strongly law enforcement of urban planning in which they were arisen to increase to have more and distributing spots of urban heat islands over all parts of Bangkok areas.

The climate of Bangkok city is naturally warm and humid, especially in rainy season (late May to early October) and summer (late February to early May) but a little cool and low humidity in winter (late October to early February). The extreme maximum ambient air temperature was on $40.1^{\circ} \mathrm{C}$ in the year of 2013 and extreme minimum air temperature on $7.7^{\circ} \mathrm{C}$ in 1974 (see Table 1) which is included the average values of annual rainfall $1,648 \mathrm{~mm}$, mean of rainy $129.9 \mathrm{~mm}$., storm intensity 77.4 days, relative humidity $73 \%$, annual pan evaporation $1,678.5 \mathrm{~mm}$, wind speed 2.9 knots, sunshine period 2,327.9 hours.

Table 1. Climatological data of Bangkok city as recorded during year 1961 and 2013 for about 53 year records by Meteorological Department of Thailand including extreme maximum Evaporation and Temperature

\begin{tabular}{|c|c|c|c|c|c|c|c|c|c|}
\hline \multirow{2}{*}{ No. } & \multirow{2}{*}{ Year } & \multicolumn{2}{|c|}{ Temperature $\left({ }^{\circ} \mathrm{C}\right)$} & \multirow{2}{*}{$\begin{array}{c}\text { Maximum } \\
\text { Evaporation }\end{array}$} & \multirow{2}{*}{ No. } & \multirow{2}{*}{ Year } & \multicolumn{2}{|c|}{ Temperature $\left({ }^{\circ} \mathrm{C}\right)$} & \multirow{2}{*}{$\begin{array}{c}\text { Maximum } \\
\text { Evaporation }\end{array}$} \\
\hline & & Maximum & Minimum & & & & Maximum & Minimum & \\
\hline 1 & 2504 & 36.9 & 12.6 & 9.8 & 28 & 1988 & 36.5 & 17.4 & 9.8 \\
\hline 2 & 2505 & 37.2 & 14.1 & 13.2 & 29 & 1989 & 37.7 & 16.9 & 9.6 \\
\hline 3 & 2506 & 36.3 & 11.6 & 14.5 & 30 & 1990 & 39.5 & 16.9 & 9.3 \\
\hline 4 & 2507 & 36.9 & 14.7 & 13.0 & 31 & 1991 & 37.8 & 19.1 & 11.5 \\
\hline 5 & 2508 & 37.1 & 16.0 & 9.8 & 32 & 1992 & N/A & 15.7 & $\mathrm{~N} / \mathrm{A}$ \\
\hline 6 & 2509 & 38.5 & 16.6 & 18.6 & 33 & 1993 & 38.4 & 14.0 & N/A \\
\hline 7 & 2510 & 37.9 & 12.9 & 8.6 & 34 & 1994 & 38 & 17.2 & N/A \\
\hline 8 & 2511 & 37.8 & 15.9 & 7.9 & 35 & 1995 & 37.8 & 14.0 & 12.9 \\
\hline 9 & 2512 & 36.9 & 15.1 & 9.4 & 36 & 1996 & 37.9 & 17.3 & 13.2 \\
\hline 10 & 2513 & 37.1 & 18.3 & 10.9 & 37 & 1997 & 37.4 & 19.2 & 10.3 \\
\hline 11 & 2514 & 36.8 & 13.1 & 9.2 & 38 & 1998 & 38.8 & 19.6 & 9.4 \\
\hline 12 & 2515 & 37.8 & 13.7 & 10.0 & 19 & 1999 & 37.6 & 13.2 & 10.0 \\
\hline 13 & 2516 & 38.3 & 11.9 & 7.4 & 40 & 2000 & 37.1 & 18.6 & 8.8 \\
\hline 14 & 2517 & 37.0 & 11.5 & 7.7 & 41 & 2001 & 37.4 & 18.6 & 9.8 \\
\hline 15 & 2518 & 38.7 & 10.5 & 10.4 & 42 & 2002 & 38.0 & 19.2 & 15.0 \\
\hline 16 & 2519 & 37.5 & 12.5 & 9.5 & 43 & 2003 & 38.6 & 18.1 & 9.6 \\
\hline
\end{tabular}




\begin{tabular}{|c|c|c|c|c|c|c|c|c|c|}
\hline 17 & 2520 & 37.8 & 16.4 & 10.5 & 44 & 2004 & 39.4 & 19.5 & 8.8 \\
\hline 18 & 2521 & 37.0 & 16.6 & 37.0 & 45 & 2005 & 38.1 & 17.8 & 7.6 \\
\hline 19 & 2522 & 40.0 & 17.2 & 10.5 & 46 & 2006 & 37.6 & 13.9 & 7.7 \\
\hline 20 & 2523 & 39.0 & 13.9 & 10.2 & 47 & 2007 & 38.6 & 18.1 & 8.0 \\
\hline 21 & 2524 & 37.8 & 13.9 & N/A & 48 & 2008 & 38.1 & 17.9 & 9.2 \\
\hline 22 & 2525 & 36.9 & 12.0 & 30.6 & 49 & 2009 & 39.4 & 15.5 & 10.4 \\
\hline 23 & 2526 & $\mathrm{~N} / \mathrm{A}$ & N/A & 0.0 & 50 & 2010 & 39.7 & 19.8 & 12.5 \\
\hline 24 & 2527 & 38.0 & 14.0 & 9.5 & 51 & 2011 & 39.2 & 17.6 & 10.8 \\
\hline 25 & 2528 & 39.7 & 16.0 & 10.2 & 52 & 2012 & 40 & 21.8 & 8.2 \\
\hline 26 & 2529 & 36.6 & 14.9 & 9.4 & 53 & 2013 & 40.1 & 14.0 & 7.7 \\
\hline 27 & 2530 & 37.7 & 15.2 & 9.3 & 54 & 2014 & N/A & N/A & $\mathrm{N} / \mathrm{A}$ \\
\hline
\end{tabular}

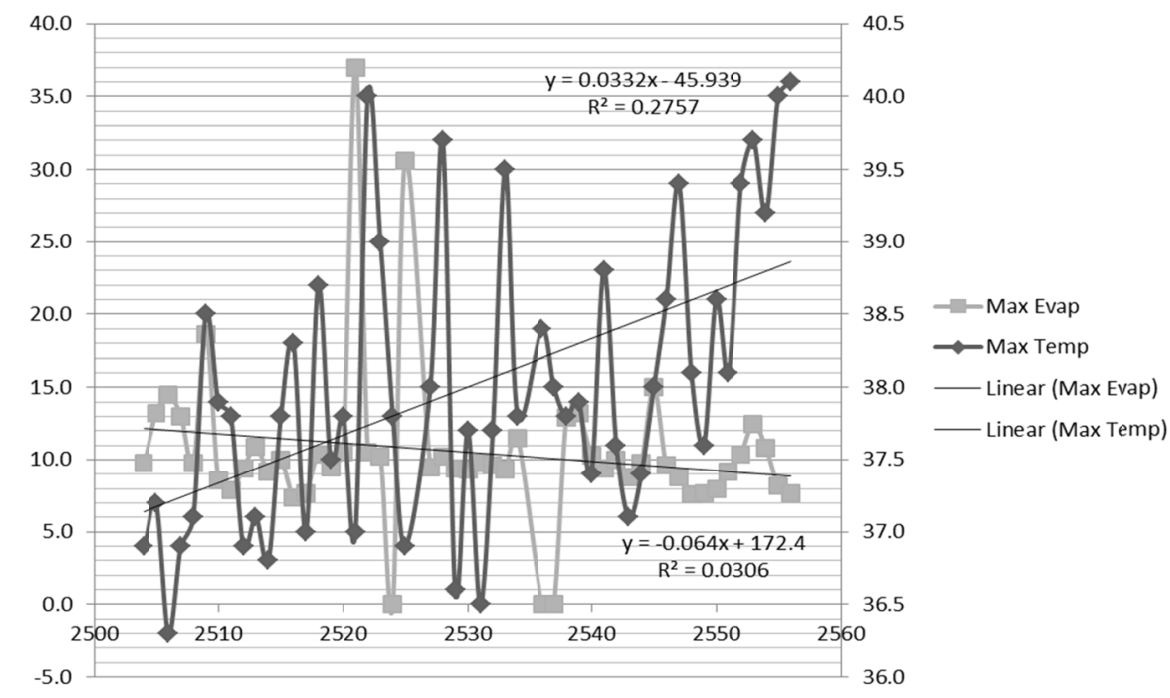

Figure 2. Fluctuation of average annual air temperature and tendency of increasing air temperature

\section{Methods and Procedures}

\subsection{Study Site Selection}

Due to homogenous distribution of rapid growth of Bangkok city which is caused to expand the urban heat island more or less temperature increasing, the study sites were selected only in the north of Bangkok (at Kasetsart University and Air Force Academy on Paholyothin road).

\subsection{Radiation Measurement}

1) Measure the incoming and outgoing of both shortwave and long wave radiation as the same as net radiometer for being used for evapotranspiration, heating air, and storage in soil on Bangkok ground surface

2) Direct measurement of net radiation, latent heat flux and sensible heat flux by 3 D IRGASON, Incorporation, (USA) as shown in Figure 3 


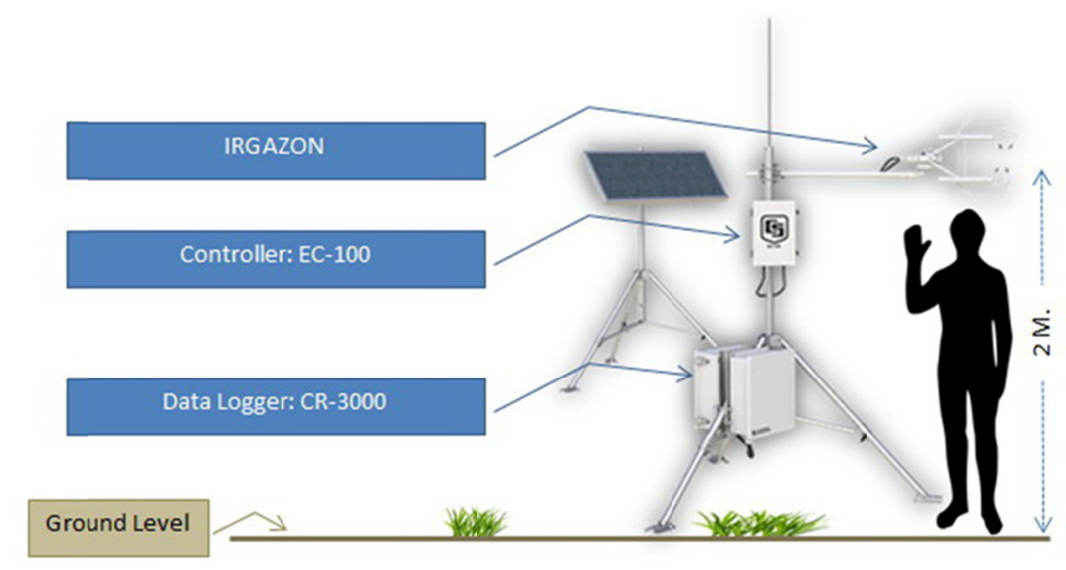

Figure 3. 3D IRGASON Anemometer and instruments, Incorporation, (USA), latent heat (LE), sensible heat (H) temperature and relative humidity probe installed at the study site

\subsection{Determination of Bowen Ratio in Relation to Cover}

Calculate the Bowen ratio which is the fraction between sensible heat to latent heat in relation to green cover $(\mathrm{G})$ and cement cover $(\mathrm{C})$ with the ratio of $100 \mathrm{G} \%: 0 \% \mathrm{C}, 75 \% \mathrm{G}: 25 \% \mathrm{C}, 50 \% \mathrm{G}$ : $50 \% \mathrm{C}, 25 \% \mathrm{G}: 75 \% \mathrm{C}$, and $0 \% \mathrm{G}$ : $100 \% \mathrm{C}$, the less the Bowen ratio is the more the green cover as the same as the less the cement cover.

\subsection{Conceptual Landscape Designing}

The optimized Bowen ratio was taken for better cooling the urban heat island as the basic criteria for conceptual designed landscape of rapid-growing city like Bangkok.

\subsection{Collection Climatic Data}

The available climatic data as belonged to Department of Meteorology will be collected in terms of rainfall and rainy day, mean air temperature, extreme minimum and maximum air temperature, air humidity, wind speed and direction, and pan evaporation. These climatic data will be emphasized on increasing air temperature as represented the urban heat island due to rapid growth in Bangkok city.

\section{Results and Discussion}

In principles, the solar radiation naturally reaches on the earth surface approximately $1.94 \mathrm{cal} / \mathrm{cm}^{2} / \mathrm{min}$ which includes both short and long waves but it might be less if the sky is composed of more impurities to absorb and/or to reflect back to the atmosphere (Sellers, 1969; Gate, 1962; Chunkao, 1971, 1979; Zhang et al., 2008; Lee, 2004). As stated before, the tree canopy is the most effective cover for more solar energy before reaching the ground surface that causing very less heating into the soils, while the construction cover, particularly concrete, in which soil's heat flux is able to obtain through the heat conduction process rather than radiation and convection processes (Deacon, 1949; Garrat, 1978; Honjo, 1990; Mangone \& Linden, 2014; Penman, 1948; Gate, 1962; Lee et al., 2004). Actually, day-time heating revealed more influence on higher temperature than the night-time temperature because of re-radiating from trees and constructed materials that directs to temperature reduction in urban heat island and how to solve such problem.

\subsection{Radiant Energy to Bangkok}

The measurement of solar radiation on 7 March 2014 (as the warmest month condition of Thailand) in the UHI sampling areas at Kasetsart University found incoming shortwave radiation approximately $0.64 \mathrm{cal} / \mathrm{cm}^{2} / \mathrm{min}$ (daily $460.8 \mathrm{cal} / \mathrm{cm}^{2}$ ), outgoing shortwave radiation $0.15 \mathrm{cal} / \mathrm{cm}^{2} / \mathrm{min}$ (daily $108.0 \mathrm{cal} / \mathrm{cm}^{2}$ and averaged albedo $23 \%$ ), incoming long wave radiation $0.58 \mathrm{cal} / \mathrm{cm}^{2} / \min$ (daily $417.6 \mathrm{cal} / \mathrm{cm}^{2}$ ), outgoing long wave radiation 0.72 $\mathrm{cal} / \mathrm{cm}^{2} / \mathrm{min}$ (daily $518.4 \mathrm{cal} / \mathrm{cm}^{2} / \mathrm{min}$, and net radiation $\left(\mathrm{R}_{\mathrm{n}}\right) 0.36 \mathrm{cal} / \mathrm{cm}^{2} / \mathrm{min}$ (daily $259.2 \mathrm{cal} / \mathrm{cm}^{2}$ ) as shown Table 2 . 
Table 2. Net radiant energy, incoming and outgoing of shortwave and long wave radiant energy as measured on 23 March 2014 at football field inside Kasetsart University Chatuchak district Bangkok province

\begin{tabular}{ccccccccc}
\hline \multirow{2}{*}{ TIME } & \multicolumn{7}{c}{ Calories/day/cm } & \\
\cline { 2 - 8 } & $\mathbf{R}_{\mathbf{S d}}$ & $\mathbf{R}_{\text {Su }}$ & $\mathbf{R}_{\text {Sd }}$ & $\mathbf{R}_{\mathbf{L u}}$ & $\mathbf{R}_{\mathbf{n}}$ & Incoming & Outgoing & Energy \\
\hline $7: 00$ & 0.03 & 0.01 & 0.56 & 0.64 & -0.06 & 0.59 & 0.65 & 35.40 \\
$8: 00$ & 0.22 & 0.05 & 0.59 & 0.66 & 0.11 & 0.81 & 0.70 & 48.64 \\
$9: 00$ & 0.52 & 0.11 & 0.56 & 0.68 & 0.29 & 1.08 & 0.79 & 64.67 \\
$10: 00$ & 0.88 & 0.19 & 0.57 & 0.71 & 0.54 & 1.45 & 0.91 & 86.80 \\
$11: 00$ & 0.75 & 0.16 & 0.58 & 0.72 & 0.46 & 1.33 & 0.87 & 79.90 \\
$12: 00$ & 1.24 & 0.27 & 0.57 & 0.75 & 0.79 & 1.81 & 1.02 & 108.53 \\
$13: 00$ & 1.26 & 0.28 & 0.58 & 0.76 & 0.79 & 1.83 & 1.04 & 110.04 \\
$14: 00$ & 1.01 & 0.23 & 0.59 & 0.77 & 0.60 & 1.60 & 1.00 & 95.87 \\
$15: 00$ & 0.82 & 0.20 & 0.59 & 0.76 & 0.46 & 1.41 & 0.95 & 84.56 \\
$16: 00$ & 0.58 & 0.15 & 0.58 & 0.74 & 0.27 & 1.16 & 0.89 & 69.77 \\
$17: 00$ & 0.33 & 0.09 & 0.58 & 0.72 & 0.10 & 0.91 & 0.81 & 54.42 \\
$18: 00$ & 0.07 & 0.02 & 0.58 & 0.69 & -0.06 & 0.65 & 0.71 & 39.06 \\
average/min & 0.64 & 0.15 & 0.58 & 0.72 & 0.36 & 1.22 & 0.86 & 73.14 \\
\hline
\end{tabular}

Total energy per day

950.79

Remark; Rn; net radiation $=0.36 \mathrm{cal} / \mathrm{cm}^{2} / \mathrm{min}$ calculated per day $0.36 \times 12 \times 60=259.2$ calories $/$ day

Average $\mathrm{R}_{\mathrm{Sd}}=0.64 \mathrm{cal} / \mathrm{cm}^{2} / \mathrm{min}$ calculated per day $=0.64 \times 12 \times 60=460.8$ calories $/$ day

Average $\mathrm{R}_{\mathrm{Su}}=0.15 \mathrm{cal} / \mathrm{cm}^{2} / \mathrm{min}$ calculated per day $=0.15 \times 12 \times 60=108$ calories $/$ day

Average $\mathrm{R}_{\mathrm{Ld}}=0.58 \mathrm{cal} / \mathrm{cm}^{2} / \mathrm{min}$ calculated per day $=0.58 \times 12 \times 60=417.6$ calories $/$ day

Average $\mathrm{R}_{\mathrm{Lu}}=0.72 \mathrm{cal} / \mathrm{cm}^{2} / \mathrm{min}$ calculated per day $=0.72 \times 12 \times 60=518.4$ calories $/$ day

Incoming solar radiation $=\mathrm{R}_{\mathrm{Sd}}+\mathrm{R}_{\mathrm{Ld}}=460.8+417.6=878.4$ energy $=950.79$ calories $/$ day

Outgoing solar radiation $=\mathrm{R}_{\mathrm{Su}}+\mathrm{R}_{\mathrm{Lu}}=108+518.4=626.4$ by average global incoming $=1.94 \times 12 \times 60=$ $1,396.8$ calories/day

In the same manner, the total incoming radiation $\left(\mathrm{R}_{\mathrm{sd}}+\mathrm{R}_{\mathrm{ld}}\right)$ was equivalent to $878.4 \mathrm{cal} / \mathrm{cm}^{2} / \mathrm{day}$ and 936.0 $\mathrm{cal} / \mathrm{cm}^{2} /$ day (hourly calculated value equivalent to $950.79 \mathrm{cal} / \mathrm{cm}^{2} /$ day) for the total outgoing radiation. While the research on energy balance at Sakaerat Environmental. Research Station in Nakhon Ratchasima, the northeastern part of Thailand, found averaged $R_{s d}, R_{s u}, R_{l d}, R_{l u}$, and $R n$ approximately 403, 50, 497, 505, and 342 g-cal $/ \mathrm{cm}^{2} /$ day, respectively, and total incoming radiant energy equivalent to $897 \mathrm{cal} / \mathrm{cm}^{2} /$ day and total outgoing radiant energy equivalent to $555 \mathrm{cal} / \mathrm{cm}^{2} /$ day (Chunkao, 1971; Chunkao, 1979) as indicated in Table 3 . It is obvious that the daily incoming radiant energy on the football field of Kasetsart University was found 878.4 $\mathrm{cal} / \mathrm{cm}^{2}$ which measured in 2013, while daily incoming radiant energy at Sakaerat Environmental. Research Station (dry-evergreen forest) was $897 \mathrm{cal} / \mathrm{v}$ which measured in 1969 . Their values were very close but the daily incoming radiant energy at Kasetsart University (Bangkok in the central, $878.4 \mathrm{cal} / \mathrm{cm}^{2}$ ) seemed lower than resulting at Sakaerat Environmental. Research Station (Nakhon Ratchasima in northeast, $897 \mathrm{cal} / \mathrm{cm}^{2}$ ). Reasonably, there might be less amount of impurities (such as gases, aerosols, mist, smokes, fly dust, and small particulates) in the atmosphere in the year of 1969 than the year of 2013. However, they could be accepted as more or less daily incoming radiant energy from sky in Thailand. In addition, when the daily outgoing radiant energy from the two study areas was comparable which found $936 \mathrm{cal} / \mathrm{cm}^{3}$ at Kasetsart University and 555 $\mathrm{cal} / \mathrm{cm}^{2}$ over dry-evergreen forest at Sakaerat Environmental Research Station. Evidently, the full green patch of dry-evergreen forest showed less amount of daily outgoing radiant energy because of shortwave solar energy is naturally absorbed for photosynthesizing process rather than lesser green patches and more concrete areas in rapid growth city like Bangkok as remarked by Sellers (1969), Heilman and Brittin (1989), Ketterer and Matzarakis (2014), Oke et al. (1991), and Verma et al. (1978), Deacon (1949), Lee et al. (2004), Gate (1962), Garrat (1978), Chunkao (1971, 1979), and Santamouris (2012). 
Table 3. Net radiant energy, incoming and outgoing of shortwave and long wave radiant energy as measured on 23 September 1969 on the top of $42 \mathrm{~m}$ tower at Sakaerat Environmental. Research Station, Pakthongchai district, Nakhon Ratchasima province, in the eastern part of Thailand

\begin{tabular}{|c|c|c|c|c|c|c|}
\hline \multirow{2}{*}{ Date } & \multicolumn{5}{|c|}{ daily radiation, $\mathrm{cal} / \mathrm{cm}^{2}$} & \multirow{2}{*}{ Sky Condition } \\
\hline & $\mathbf{R}_{\mathrm{Sd}}$ & $\mathbf{R}_{\mathrm{Su}}$ & $\mathbf{R}_{\mathbf{L d}}$ & $\mathbf{R}_{\mathrm{Lu}}$ & $\mathbf{R}_{\mathbf{n}}$ & \\
\hline 10 Jun 1970 & 626 & 75 & 450 & 514 & 487 & \\
\hline 11 Jun 1970 & 541 & 64 & 459 & 525 & 411 & \\
\hline 30 Jun 1970 & 514 & 60 & 505 & 520 & 439 & Clear \\
\hline 3 July 1970 & 581 & 67 & 441 & 497 & 458 & \\
\hline 1 August 1970 & 587 & 67 & 466 & 507 & 479 & \\
\hline 3 September 1970 & 512 & 67 & 545 & 521 & 469 & $\mathrm{r}=12 \%$ \\
\hline Average & 560 & 67 & 478 & 514 & 457 & \\
\hline 4 June 1970 & 455 & 54 & 498 & 514 & 385 & \\
\hline 5 June 1970 & 410 & 47 & 481 & 509 & 335 & \\
\hline 20 June 1970 & 459 & 56 & 489 & 505 & 387 & \\
\hline 22 June 1970 & 466 & 52 & 460 & 505 & 369 & \\
\hline 27 June 1970 & 438 & 53 & 481 & 396 & 470 & \\
\hline 1 July 1970 & 443 & 52 & 470 & 499 & 362 & Clear with \\
\hline 7 July 1970 & 445 & 58 & 489 & 485 & 391 & Partial.ly cloud \\
\hline 13 August 1970 & 440 & 52 & 483 & 480 & 391 & \\
\hline 15 August 1970 & 431 & 63 & 480 & 514 & 334 & \\
\hline 22 August 1970 & 440 & 55 & 405 & 485 & 305 & \\
\hline 1 September 1970 & 401 & 43 & 459 & 494 & 323 & $\mathrm{r}=12 \%$ \\
\hline Average & 490 & 59 & 516 & 536 & 410 & \\
\hline 9 June 1970 & 394 & 51 & 474 & 511 & 306 & \\
\hline 28 June 1970 & 350 & 44 & 492 & 504 & 294 & \\
\hline 29 June 1970 & 352 & 45 & 483 & 500 & 290 & \\
\hline 1 July1970 & 382 & 47 & 454 & 497 & 292 & \\
\hline 6 July 1970 & 361 & 46 & 494 & 502 & 307 & Cloudy with \\
\hline 4 August 1970 & 315 & 41 & 483 & 491 & 266 & Partially rain \\
\hline 14 August 1970 & 392 & 46 & 485 & 508 & 323 & \\
\hline 17August 1970 & 331 & 42 & 485 & 506 & 268 & $r=13 \%$ \\
\hline Average & 360 & 45 & 481 & 502 & 293 & \\
\hline 3 June 1970 & 214 & 26 & 488 & 510 & 166 & \\
\hline 8 June 1970 & 256 & 30 & 497 & 512 & 211 & \\
\hline 21 June 1970 & 221 & 27 & 485 & 497 & 182 & \\
\hline 26 June 1970 & 239 & 31 & 471 & 503 & 176 & \\
\hline 8 July 1970 & 287 & 37 & 470 & 486 & 234 & Cloudy and rain \\
\hline 9 July 1970 & 290 & 39 & 490 & 493 & 248 & \\
\hline 29 July 1970 & 42 & 8 & 750 & 540 & 244 & \\
\hline 30 July 1970 & 72 & 14 & 878 & 538 & 398 & \\
\hline 2 August 1970 & 197 & 24 & 483 & 496 & 160 & \\
\hline 16 August 1970 & 255 & 32 & 473 & 490 & 206 & \\
\hline 23 August 1970 & 241 & 31 & 492 & 501 & 201 & \\
\hline 2 September 1970 & 282 & 38 & 502 & 510 & 236 & \\
\hline 9 September 1970 & 264 & 40 & 501 & 512 & 213 & $r=13 \%$ \\
\hline Average & 204 & 27 & 499 & 468 & 208 & \\
\hline Total. Average & 403 & $\mathbf{5 0}$ & 494 & 505 & 342 & $\mathrm{r}=12 \%$ \\
\hline
\end{tabular}

Remarks; 1. Total incoming radiant energy $\left(\mathrm{R}_{\mathrm{Sd}}+\mathrm{R}_{\mathrm{Ld}}\right)$ equivalent to $897 \mathrm{cal} / \mathrm{cm}^{2} /$ day; 2 . Total incoming radiant energy $\left(\mathrm{R}_{\mathrm{Su}}+\mathrm{R}_{\mathrm{Lu}}\right)$ equivalent to $555 \mathrm{cal} / \mathrm{cm}^{2} /$ day.

\subsection{Increase of Temperature in Bangkok}

The elderly Bangkok residents insisted on climatic conditions that not only has been gradually increased but it has also changed in time and space since the year of 1917, because of gradually increasing roads, households, buildings, and man-made construction without specific land use planning. In the same way, the green areas for 
latent heat reduction have been replaced by sensible heat increasing in which the urban heat islands tended to distribute all parts of the city of Bangkok as seen at the present time. Inconsequence, the ambient air temperature has to gradually increase (see Figure 4) which is caused by increasing of constructed materials absorbing heat from solar radiation before re-radiating as sensible heat in surrounding areas. However, the average ambient air temperature, as shown in Figure 2, could be estimated about $1.5{ }^{\circ} \mathrm{C}$ for 56 -year records $\left(0.03{ }^{\circ} \mathrm{C} /\right.$ year $)$ during 1957 to 2013 from Phra Khanong Climatic Station (center of Bangkok city at the present time) as located on Sukhumvit road and operated by Meteorological Department which has been established in 1927. Fortunately, Bangkok city is located in tropical zone and surrounded with water sources of Chao Phraya river and the Gulf of Thailand that causing the low rate of temperature increase due to less temperature gradient as stated by Penman (1948), Linsley et al. (1988), and Chunkao (1971).

\section{Temp}

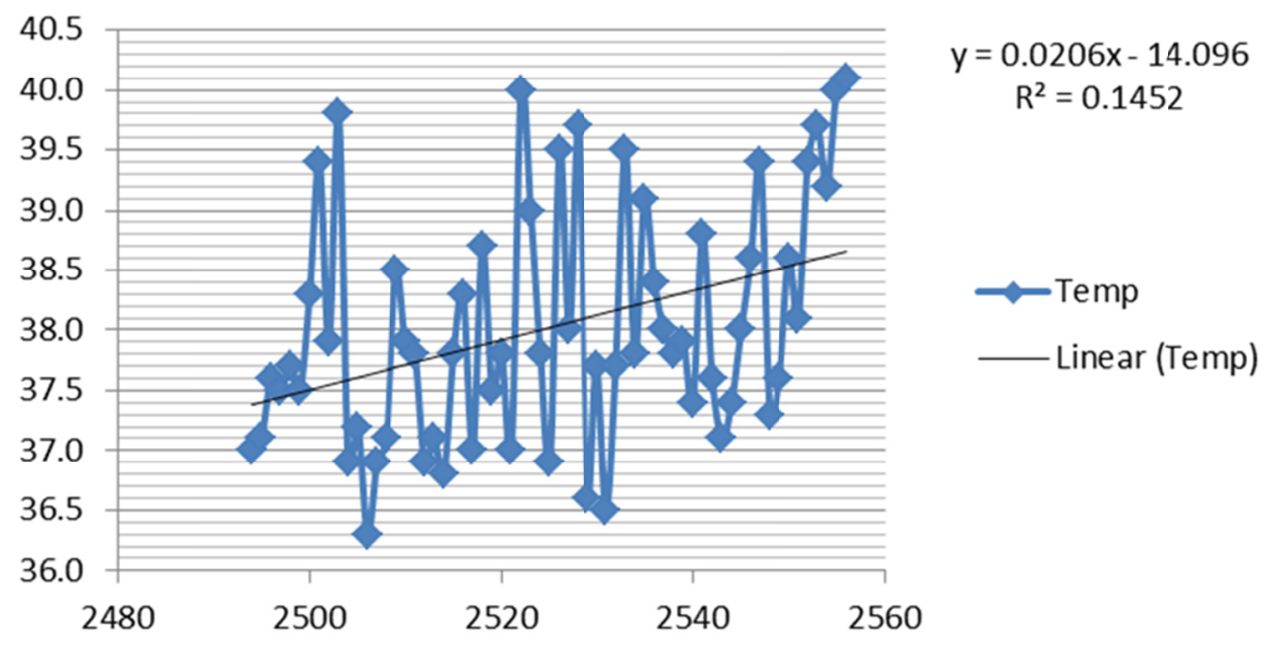

Figure 4. Ambient air temperature as recorded during 1957 to 2013 at Phra Khanong Climatic Station, the center of Bangkok city at the present time, on Sukhumvit road by operated by Meteorological Department, Ministry of Transportation, Thailand

Obviously, Bangkok city is indicated the tendency of increasing ambient air temperature due to rapid growth together with constructing concrete and asphalt concrete roads, sky trains, shop houses, shopping centers, buildings, tall buildings, places of amusement, sport complex, government offices, religious places, clinics and hospitals in which they are named as the point sources of urban heat islands that turns to make temperature increasing in all parts of Bangkok as seen in the present time (Honjo \& Takakura, 1990; Santamouris, 2012; Sun and Augenbroe, 2014; Lokoshchenko, 2014; Ketterer \& Matzarakis, 2014; Oke et al., 1991; Takebayashi et al., 2014).

\subsection{Bowen Ratio and Green-Cement Patching}

There were a lot of methods for determining the urban heat island in rapid growth cities as well as the dense constructing buildings in order to obtain a guideline for reduction ambient air temperature by using evaporating water as heat absorbent (Peres et al., 1999; Wolf et al., 2008; Uddin et al., 2013; Heilman \& Brittin, 1989; Holland et al., 2013; Dicken et al., 2013; Ng et al., 2012; Savage et al., 2009). By taking the principles and methodologies from those scientists as aforesaid statement, the Bowen ratio was applicable to determine heat storage in urban heat island. Accordance with Bowen ratio is described as the ratio between sensible heats to latent heat (Bowen, 1926). If the result is less than one and it goes closer to zero, there must be very less chance to have an urban heat island because of the latent heat as denominator getting bigger that resulting smaller. In opposite, the sensible heat is increased, and then the latent heat becomes smaller that makes the Bowen ratio has to come up with larger in numbers.

Intentionally, the study was focused on the proportion between the percentages of green $(\mathrm{G})$ and cement $(\mathrm{C})$ 
patches in terms of $\mathrm{G} 100 \% \mathrm{C} 0 \%, \mathrm{G} 75 \% \mathrm{C} 25 \%, \mathrm{G} 50 \% \mathrm{C} 50 \%, \mathrm{G} 25 \% \mathrm{C} 75 \%$, and $\mathrm{G} 0 \% \mathrm{C} 100 \%$ in relation to time of the day (23 February 2014 to 14 March 2014), and also proportion among tree (T), green patch (G), and water surface (W) were experimented in order to make use in landscape designing for temperature reduction in urban heat island by selecting the north Bangkok at football field of Kasetsart University as the representative area. The results were revealed in Table4 which indicated that the averaged Bowen ratio was 0.19 for proportion of $\mathrm{G} 100 \% \mathrm{C} 0 \%, 2.58$ for $\mathrm{G} 75 \% \mathrm{C} 25 \%, 3.25$ for $\mathrm{G} 50 \% \mathrm{C} 50 \%, 3.20$ for $\mathrm{G} 25 \% \mathrm{C} 75 \%$, and 5.18 for $\mathrm{G} 0 \% \mathrm{C} 100 \%$. In other words, the increases of cement patches were stimulated to increase heat due to lack of supplying water to withdraw heat by evapotranspiration processes (Honjo and Takakura, 1990; Santamouris, 2012; Akbari et al., 1992; McPherso and Rowntree, 1993). When the green patch grew trees about $50 \%$ of the area in proportion of $\mathrm{T} 50 \% \mathrm{G} 50 \%$, the averaged Bowen ratio was 0.41 , as the same as the proportion of $\mathrm{T} 50 \% \mathrm{~W} 50 \%$ found the Bowen ratio of 0.39 , and G85\%W15\% found Bowen ratio about 0.20 as shown in Table 4, The last statements were learnt that the urban heat island should be cooled in case of taking some spaces for growing trees and constructing water storage areas (see Table 4). Obviously, the cement patches, especial.ly concrete buildings and roads, caused the increase of heat such as $\mathrm{C} 33 \% \mathrm{~T} 33 \% \mathrm{~W} 33 \%$ (Bowen ratio 0.63 ) and $\mathrm{C} 50 \% \mathrm{~W} 50 \%$ (Bowen ratio 0.99) which pointed out that the stakeholders have to keep in mind before bringing the cement or concrete into the given patches.

Table 3. Bowen ratio of proportion between percentages of green and cement patches in relation to time of the day, from 07:00 to 18:00

\begin{tabular}{|c|c|c|c|c|c|c|c|c|c|c|c|}
\hline \multirow[b]{2}{*}{ No. } & \multirow[b]{2}{*}{ Time } & \multicolumn{10}{|c|}{ Bowen Ratio } \\
\hline & & G100\% & $\begin{array}{l}\text { G75\% } \\
\text { C25\% }\end{array}$ & $\begin{array}{l}\text { G50\% } \\
\text { C50\% }\end{array}$ & $\begin{array}{l}\text { G25\% } \\
\text { C75\% }\end{array}$ & $\mathrm{C} 100 \%$ & $\begin{array}{l}\text { T50\% } \\
\text { G50\% }\end{array}$ & $\begin{array}{r}\text { T50\% } \\
\text { W50\% }\end{array}$ & $\begin{array}{c}\text { C33.3\% } \\
\text { T33.3\%W33.3\% }\end{array}$ & $\begin{array}{l}\text { G85\% } \\
\text { W15\% }\end{array}$ & $\begin{array}{r}\mathrm{C} 50 \% \\
\mathrm{~W} 50 \%\end{array}$ \\
\hline 1 & $7: 00$ & -0.03 & 1.08 & 1.59 & 1.74 & 4.14 & 0.04 & 0.28 & 0.05 & -0.11 & 0.72 \\
\hline 2 & $8: 00$ & 0.40 & 1.45 & 1.03 & 2.33 & 7.16 & 0.25 & 0.53 & 0.05 & 0.24 & 0.78 \\
\hline 3 & $9: 00$ & 0.32 & 2.92 & 3.02 & 3.00 & 3.38 & 0.80 & 0.39 & 1.08 & 0.20 & 1.00 \\
\hline 4 & $10: 00$ & 0.22 & 2.47 & 3.80 & 2.16 & 7.12 & 0.73 & 0.60 & 1.49 & 0.42 & 1.02 \\
\hline 5 & $11: 00$ & 0.23 & 3.55 & 2.57 & 1.49 & 5.27 & 0.55 & 0.45 & 2.24 & 0.37 & 1.17 \\
\hline 6 & $12: 00$ & 0.30 & 3.54 & 3.69 & 1.76 & 8.61 & 0.44 & 0.31 & 0.51 & 0.31 & 0.37 \\
\hline 7 & $13: 00$ & 0.26 & 3.61 & 2.41 & 3.04 & 2.33 & 0.46 & 0.17 & 0.43 & 0.29 & 0.68 \\
\hline 8 & $14: 00$ & 0.24 & 3.99 & 5.58 & 4.40 & 1.47 & 0.43 & 0.24 & 0.54 & 0.29 & 1.34 \\
\hline 9 & $15: 00$ & 0.23 & 4.90 & 1.06 & 8.33 & 3.17 & 0.39 & 0.57 & 0.54 & 0.20 & 1.46 \\
\hline 10 & $16: 00$ & 0.18 & 3.10 & 6.39 & 5.77 & 8.70 & 0.32 & 0.53 & 0.28 & 0.12 & 1.42 \\
\hline 11 & $17: 00$ & 0.09 & 0.13 & 0.92 & 2.84 & 7.93 & 0.49 & 0.39 & 0.04 & 0.09 & 0.78 \\
\hline 12 & 18:00 & -0.11 & 0.20 & 6.97 & 1.51 & 2.90 & 0.05 & 0.19 & 0.32 & -0.03 & 1.19 \\
\hline \multicolumn{2}{|c|}{ Average } & 0.19 & 2.58 & 3.25 & 3.20 & 5.18 & 0.41 & 0.39 & 0.63 & 0.20 & 0.99 \\
\hline
\end{tabular}

Remarks: $\mathrm{G}=$ green cover/patch; $\mathrm{C}=$ cement cover; $\mathrm{T}=$ tree cover; $\mathrm{W}=$ water area.

Since, the atmosphere cannot stay still but it moves all direction and it also affected to latent heat and sensible heat, surely in consequence to the Values of Bowen ratio in relation to time. Therefore, there were quite fluctuation of Bowen ratio from time to time and from one proportion to the other proportion of Green and Cement patches (see Table 4). However, the urban heat island was evidently performed after mid-day time, particularly between 13:00 to 16:00 in clear sky because the cement patches had to spend some time of heating ambient air temperature rather than before noon which exists more water vapor on the surface and sun-beam direction to relieve the cement heating. It is remarkable from separated experiment that the Bowen ratios were inversely relied on latent heat, and directly on sensible heat and air temperature as shown in Table 5 and Figure 5 . The Bowen ratio ranged between 0.19 to 4.13 which were more or less than the previous experiments such as Savage et al. (2009), Ng et al. (2012), Dicken et al. (2013), Holland et al. (2013), Peres et al. (1999), Uddin et al. (2013), and Wolf et al. (2008). In consequence, the Bowen ratio is applicable for studying on the urban heat island phenomenon in rapid growth cities as the same as the areas with dense buildings, houses, and others. This study pointed out that the proportion of $\mathrm{G} 25 \% \mathrm{C} 75 \%$ (Bowen ratio equivalent to 3.20 ) to $\mathrm{G} 50 \% \mathrm{C} 50 \%$ (Bowen ratio equivalent to 3.2) would be appropriate to take part for city planning to reduce ambient air temperature in urban heat island one way or another. Actually, the highest air temperature $\left(33.02{ }^{\circ} \mathrm{C}\right)$ was placed on the $\mathrm{G}-\mathrm{C}$ 
proportion of G25\%C75\% (see Table 5 and Figure 5) that could be solved by growing trees and constructing pond for extracting heat under the transpiration and evaporation from soil water and free water surface.

Table 4. Bowen ratio, latent heat and sensible heat fluxes, and ambient air temperature as measured during 23 February 2014 to 14 March 2014 at football field of Kasetsart University as the sampling site of urban heat island in north Bangkok

\begin{tabular}{|c|c|c|c|c|}
\hline \multirow{2}{*}{ Land use } & \multicolumn{2}{|c|}{ Gm-cal $/ \mathrm{cm}^{2} / \mathbf{m i n}$} & \multirow{2}{*}{ Bowen Ratio } & \multirow{2}{*}{$\operatorname{Temp}\left({ }^{\circ} \mathrm{C}\right)$} \\
\hline & $\mathbf{H}$ & $\mathbf{L E}$ & & \\
\hline $\mathrm{G} 100 \% \mathrm{C} 0 \%$ & 3.14 & 13.61 & 0.19 & 30.88 \\
\hline G75\% C25\% & 6.87 & 3.21 & 2.58 & 30.29 \\
\hline G50\% C $50 \%$ & 5.93 & 2.56 & 3.25 & 31.77 \\
\hline $\mathrm{G} 25 \% \mathrm{C} 75 \%$ & 7.10 & 2.71 & 3.20 & 33.02 \\
\hline G0\% C100\% & 5.45 & 1.35 & 4.13 & 31.56 \\
\hline
\end{tabular}

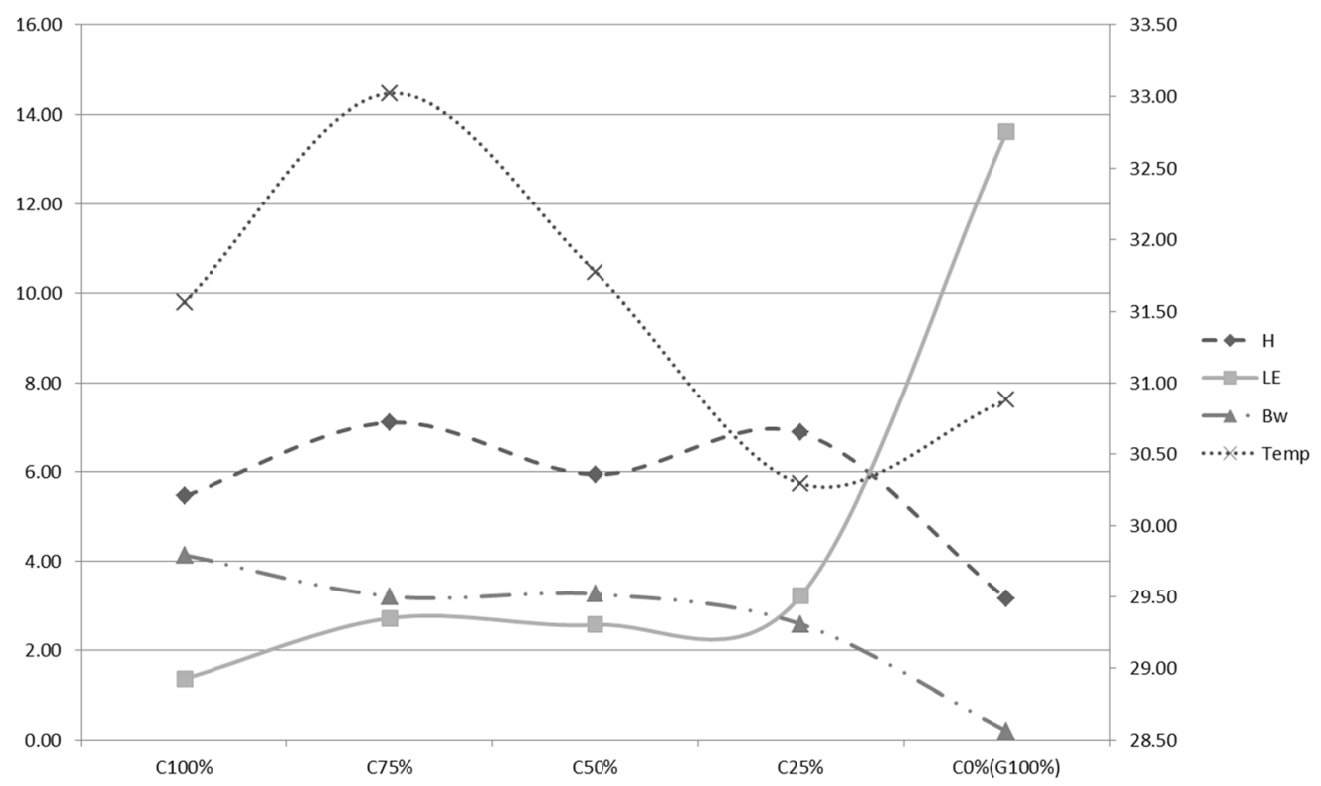

Figure 5. Relationship between Bowen ratio, latent heat and sensible heat fluxes, and given green-cement patches to time of the day as measured on 23 February 2014 to 14 March 2014

\subsection{Proposed Landscape Designing}

Summarily speaking, the sizes of green patch between $\mathrm{G} 25 \%$ to $\mathrm{G} 50 \%$ as well as $\mathrm{C} 50 \%$ to $\mathrm{C} 75 \%$ of the city were chosen as the appropriate areas for putting in the landscape in terms of growing trees and pond construction as the heat absorbents as said by Honjo and Takakura (1990), Santamouris (2011, 2012), Akbari et al. (1992), Oke et al. (1991), Maimaitiyiming et al. (2014), and Takebayashi et al. (2014). In principles, the latent heat plays vital role in transferring heat through the vegetative transpiration and water evaporation processes but depending on the five factors such as ambient air temperature, water availability and quality, wind velocity, atmospheric moisture, plant species (Linsley et al. 1988, Penman 1948, and Chunkao 1971, 2008). Normally, the daily evapotranspiration of Thailand ranged $3.0 \mathrm{~mm}$ in highlands, $12 \mathrm{~mm}$ in paddy fields and $15 \mathrm{~mm}$ in reservoirs or storage dam. With this knowledge background, utilization of tree growing as well as city parks and constructing ponds should be considered in landscape designing (Zhang et al., 1978; Mangone \& Linden, 2014; Ng et al., 2012). No matter growing trees or pond construction for reducing air temperature in urban heat island, the green spaces and sustainable design of urban environment have to consider with care, especially locating the city parks, ponds, courtyards, roadsides and road isles, and public areas (Maimaitiyiming et al., 2014; Shahiden et al., 2012; McPherson, 1988; McPherson \& Simpson. 1992; McPherson \& Rowntree, 1993; Ng et al., 2012; Skoulika et al., 


\section{4; Sun \& Augenbroe, 2014).}

Based on the research results, the landscape design for healthy and comfortable livelihood in the city of concrete constructions and dense population is proposed the basic principles for heat reduction of UHI areas by localizing the green patches in the following orders of magnitude:-

Order 1: Landscape Macro-Designing transportation, living areas, shopping location, government center, education, sports, industrial estates, waste management areas, green patches.

Order 2: Green Patch Localization pond construction, city parks, botanical gardens, flower gardens, arboretums, roadside strip-tree growing, road isle tree planting.

Order 3: Cooling Housing Design and Construction, formed-height-shaped houses and buildings; ventilation-energy-saving constructions, architectural design, local identity, housing location, constructed-housing space.

Order 4: Housing Landscape Design courtyards, tree planting, house gardens, swimming pool, aquatic animal culturing, green roof, climbers, surrounding green patching, and potted plants.

The above orders of magnitude should be named as the appropriate measure techniques for heat reduction in the areas of urban heat islands as collected from previous researchers such as Takebayashi et al. (2014), Zhang et al. (2013), Akbari et al. (1992), Santamouris (2012), Ketterer and Matzarakis (2014), Honjo and Takakura (1990), Mangone and Linden (2914), Ng et al. (2012), McPherson (1988), McPherson and Simpson (1992), McPherson and Rowntree (1993), Shahidan et al. (2012), and Maimaitiyiming et al. (2014). The most important issue would be how to cool the urban heat islands and dwellings in the city of dense populated and concrete constructions. All mentioned researchers have received their results for supporting that the UHI and dwellings cooling should be emphasized on community and strip tree planting, swimming pool and pond construction, and open-green spaces; and al.so it still concerns in forms, heights, shape, colors, wind circulation, and heat storage and re-radiating materials in order to extract heat from UHI unit areas.

\section{Conclusion}

Due to the rapid growth of urban heat island (UHI) in Bangkok, which is covered by 1,568.7 sq.km and 1.5 mMSL and surrounded by the Gulf of Thailand and Chao Phraya river, has been gradually extended through suburban areas that making ambient air temperature increased about $0.03{ }^{\circ} \mathrm{C} /$ year for 56 -year period $(1957$ to 2013) but extreme ambient air temperature in the decade went up more $39^{\circ} \mathrm{C}$ in late February throughout early April. The heat reduction by green patches which are composed of vegetation and open-surface pond through the evapotranspiration process was taken in this research. Bowen ratio, which is the ratio between sensible heat flux and latent heat flux was selected for determining its dimensionless values as the indicators to pinpoint the appropriate green patches in using for landscape design to achieve full function of heat reduction in the UHI unit area. The experimental results found as follows:

1) The radiant energy which measured in 2014 at football field of Kasetsart University found daily radiant energy $R_{\text {sd }} 460,8, R_{\text {su }} 108.0, R_{l d} 417.6, R_{l u} 518.4, R_{n} 259.2$, and $\left(R_{s d}+R_{l d}\right) 878.4$ gm-cal $/ \mathrm{cm} 2 /$ day; while in Nakhon Ratchasima (measured in 1970) $R_{\text {sd }} 403, R_{\text {su }} 50, R_{l d} 497, R_{l u} 505, R_{n} 342$, and $\left(R_{s d}+R_{l d}\right) 897$ $\mathrm{g}-\mathrm{cal} / \mathrm{cm}^{2} /$ day. It shows somewhat equal incoming radiant energy on both areas but outgoing radiant energy at Kasetsart University $626.4 \mathrm{~g}-\mathrm{cal} / \mathrm{cm}^{2} /$ day and Nakhon Ratchasima $555 \mathrm{~g}-\mathrm{cal} / \mathrm{cm}^{2} /$ day because of more sensible heat flux at Kasetsart University (Bangkok). Also, more net radiation found in Nakhon Ratchasima (342 gm-cal $/ \mathrm{cm}^{2} /$ day that Kasetsart University $\left(259.2 \mathrm{~g}-\mathrm{cal} / \mathrm{cm}^{2} /\right.$ day) due to mostly latent heat flux.

2) The values of Bowen ratio were found 3.20 and 3.25 as pinpointed to the appropriate green patches between $25 \%$ to $75 \%$ of designing landscape that should be enough to reduce temperature in the UHI unit areas.

3) The research results learnt that there were four orders of magnitude to use for landscape designing, i.e., landscape macro-designing, green patch localization, cooling house designing and construction, and housing landscape designing.

4) Lesson learnt from this research that the city/urban planning is really needed the body of knowledge on how to localize the green patches for long term reducing heat in the expected UHI unit areas and supporting healthy and wealthy livelihood.

\section{References}

Akbari, H., Susan D., Sofia, D., Joe, H., \& Steven, W. (1992). Cooling Our Communities: A Guidebook on Tree Planting and Light-Colored Surfacing. U.S. Environmental Protection Agency, Office of Policy Analysis, 
Climate Change Division, Washington, D.C.

Alchapar, N. L., Correa, E. N., \& Canton, M. A. (2014). Classification of building materials used in the urban envelopes according to their capacity for mitigation of the urban heat island in semiarid zones. Energy and Buildings, 69, 22-32. http://dx.doi.org/10.1016/j.enbuild.2013.10.012

Ashktorab, H., Pruitt, W. O., Paw U., K. T., \& George, W. V. (1989). Energy balance determination close to the soil surface using a micro-Bowen ratio system. Agricultural and Forest Meteorology, 46, $259-274$. http://dx.doi.org/10.1016/0168-1923(89)90068-3

Bowen, I. S. (1926). The ratio of heat losses by conduction and by evaporation from any water surface. Physical Review, 27, 779-783.

Caseo, P., \& Larsen, L. (2014). How factors of land use/ land cover, building configuration, and adjacent heat sources and sinks explain Urban Heat Island. Landscape and Urban Planning, 125, 117-129. http://dx.doi.org/10.1016/j.landurbplan.2014.02.019

Chun, B., \& Guldman, J. M. (2014). Spatial statistical analysis and simulation of urban heat island in high-intensity central cites. Landscape and Urban Planning, 125, 76-88. http://dx.doi.org/10.1016/j.landurbplan.2014.01.016

Chunkao, K. (1971). An analysis of evapotranspiration of dry-evergreen forest at Sakareat, Thailand. KU Forest research Bulletin, 16.

Chunkao, K. (1979). Micrometeorology (p. 147). Department of Conservation, Faculty of Forestry, Kasetsart University, Bangkok, Thailand.

Chunkao, K. (2008). Principles of Watershed Management (p. 341). Kasetsart University Publishers, Bangkok, Thailand.

Deacon, E. L. (1949). Vertical diffusion in the lowest layers of the atmosphere. Quarterly Journal of Royal Meteorological Society, 75.

Dicken, U., Cohen, S., \& Tanny, J. (2013). Examination of the Bowen ratio energy balance technique for evapotranspiration estimates in screen houses. Biosystems Engineering, 114, 397-405. http://dx.doi.org/10.1016/ 10.1016/j.biosystemseng.2012.11.001

Garrat, J. R. (1978). Flux profile relations above tall vegetation. Quarterly Journal of Royal Meteorological Society, 104, 199-211. http://dx.doi.org/10.1016/ 10.1002/qj.49710443915

Gate, D. M. (1962). Energy Exchange in the Biosphere (p. 170). Harper and Row, New York.

Heilman, J. I., \& Brittin, C. I. B. (1989). Fetch requirements for Bowen ratio measurements of latent and sensible heat fluxes. Agricultural and Forest Meteorology, 44, 261-273. http://dx.doi.org/10.1016/0168-1923(89)90021-X

Holland, S., Heilman, J. I., Honward, A., Saver, T. J., Geise, W., Ben-Gat, A., Agam, N., Kool, D., \& Harlin, J., (2013). Micro-Bowen ratio system for measuring evapotranspiration in a vineyard interrow. Agricultural and Forest Meteorology, 177, 93-100. http://dx.doi.org/10.1016/j.agrformet.2013.04.009

Honjo, T., \& Takakura, T. (1990). Simulation of thermal effects of urban green areas on their surrounding areas. Energy and Building, 15(16), 443-446. http://dx.doi.org/ 10.1016/0378-7788(90)90019-F

Ketterer, C., \& Matzarakis, A. (2014). Human-biometeorological assessment of the urban heat island in a city with complex topography-the case of Stuttgart, Germany. Urban Climate, (in press). http://dx.doi.org/ 10.1016/j.uclim.2014.01.003

Lee, X., Massman, W., \& Law, B. E. (2004). Handbook of micrometeorology: A guide for surface flux measurement and analysis (p. 250). Dordrecht, Kluwer Academic Press.

Linsley, R. K., Paulhus, J. L., \& Wallace, J. S. (1988). Hydrology for engineering (p. 492). McGrawhill Book Company, New York, SI Metric Edition.

Lokoshchenko, M. A. (2014). Urban heat island in Moscow. Urban Climate (in press). http://dx.doi.org/ 10.1016/j.uclim.2014.01.008

Maimaitiyiming, M., Ghulam, A., Tiyip, T., Pla, P., Latorre-Carmouna, P. Halik, U., Sawut, M., \& Caetono, M. (2014). Effects of green space spatial pattern on land surface temperature: Implementations for sustainable urban planning and climate change adaptation. ISPRS Journal. of Photogrammetry and Remote Sensing, 89, 59-66. http://dx.doi.org/10.1016/j.isprsjprs.2013.12.010 
Mangone, G., \& Von der Linden, K. (2014). Forest Microclimate: Investigating the performance potential. of vegetation at the building space scale. Building and Environment, 73, 12-23. http://dx.doi.org/ 10.1016/j.buildenv.2013.11.012

McPherson, E. G., \& Rowntree, R. A. (1993). Energy conservation potential of urban tree planting. Journal of Arboriculture, 19, 321-331.

McPherson, E. G., \& Simpson, T. R. (1992). Potential energy savings in buildings by an urban tree planting programme in California. Urban Forestry and Urban Green, 2, 73-86. http://dx.doi.org/10.1078/1618-8667-00025

McPherson, E. G. (1988). 16.Functions of buffer planting in urban environments. Agriculture, Ecosystems, and Environment, 22/23, 281-298. http://dx.doi.org/10.1016/0167-8809(88)90026-6

Ng, E., Chen, L., Wang, Y., \& Yuan, C. (2012). A study on the cooling effects of greening in a high-density city: An experience from Hong Kong. Building and Environment, 47, 256-271. http://dx.doi.org/10.1016/j.buildenv.2011.07.014

Oke, T. R., Johnson, D. G., Steyn, D. G., \& Watson. I. D. (1991). Simulation of surface urban heat island under ideal. conditions at night - Part 2: Diagnosis and causation. Boundary-Layer Meteorology, 56, 339-358.

Penman, H. L. (1948). Natural evaporation from open water, bare soil, and grass. Royal Society London Proceedings (Series A), p193.

Peres, P. J., Castellvi, F., Ibanez, M., \& Rosell, J. I. (1999). Assessment of reliability of Bowen ratio method for partitioning fluxes. Agricultural and Forest Meteorology, 97, 141-150. http://dx.doi.org/10.1016/S0168-1923(99)00080-5

Santamouris, M. (2001). Energy and climate in the Urban Built Environment. James and James Science Publishers, London.

Santamouris, M. (2012). Cooling the cities-A review of reflective and green roof mitigation technologies to fight heat island and improve comfort in urban environments. Solar Energy (in press).

Savage, M. J., Everson, C. S., \& Metelerkamp, B. R. (2009). Bowen ratio evaporation measurement in a remote montane grassland: Data integrity and flux. Journal of Hydrology, 376, 249-260. http://dx.doi.org/10.1016/j.solener.2012.07.003

Sellers, W. D. (1969). Climatology (p. 272). Chicago, and London, The University of Chicago Press.

Shahidan, M. F., Jones, P. J., Gwillium, J., \& Salleh, E. (2012). An evaluation of outdoor and building environment cooling achieved through combination modification of trees with ground materials. Building and Environment, 58, 245-257. http://dx.doi.org/10.1016/j.buildenv.2012.07.012

Skoulika, F., Santamouris, M., Kolokotsa, D., \& Boemi, N. (2014). On the thermal characteristics and mitigation potential of a medium size urban park in Athens, Greece. Landscape and Urban Planning, 123, 73-86.

Sun, Y., \& Augenbroe, G. (2014). Urban heat island effect on energy application studies of office buildings. Energy and Buildings, 77, 171-179.

Swinbank, W. C. (1951). The measurement of vertical transfer of heat and water vapor by eddies in the lower $\begin{array}{lllll}\text { atmosphere. Journal } & \text { Meteorology, } & 8, & \text { 135-145. }\end{array}$ http://dx.doi.org/10.1175/1520-0469(1951)008<0135:TMOVTO >2.0.CO;2

Takebayashi, H., Kimuara, Y., \& Kyogoku, S. (2014). Study on the appropriate selection of urban heat island measure technologies to urban block properties. Sustainable Cities and Society (in press). http://dx.doi.org/10.1016/j.scs.2014.01.008

Uddin, J., Hancock, N. H. Smith, R. J., \& Foley, J. P. (2013). Measurement of evapotranspiration during sprinkler irrigation using a precision energy budget (Bowen ratio, eddy covariance) methodology. Agricultural Water Management, 116, 89-100. http://dx.doi.org/10.1016/j.agwat.2012.10.008

Verma, S. B., Rosemberg, N. J., \& Blad, B. L. (1978). Turbulent exchange coefficients for sensible heat and water vapor under advective conditions. Journal of Applied Meteorology, 17, 330-338. http://dx.doi.org/10.1175/1520-0450(1978)017<0330:TECFSH $>2.0$. CO;2

Wolf, A., Saliendra, N., Akshalov, K., Johnson, D. A., \& Laca, E. (2008). Effects of different eddy covariance correlation schemes on energy balance closure and comparisons with the modified Bowen ratio systems. Agricultural and Forest Meteorology, 148, 942-952. http://dx.doi.org/ 10.1016/j.agrformet.2008.01.005 
Zhang, Z., Lv, Y., \& Pan, H. (2013). Cooling and humidifying effect of plant communities in subtropical urban parks. Urban Forestry and Urban Greening, 12, 323-329. http://dx.doi.org/ 10.1016/j.ufug.2013.03.010

\section{Copyrights}

Copyright for this article is retained by the author(s), with first publication rights granted to the journal.

This is an open-access article distributed under the terms and conditions of the Creative Commons Attribution license (http://creativecommons.org/licenses/by/3.0/). 